\title{
TWO ORCOKININS AND THE NOVEL OCTAPEPTIDE ORCOMYOTROPIN IN THE HINDGUT OF THE CRAYFISH ORCONECTES LIMOSUS: IDENTIFIED MYOSTIMULATORY NEUROPEPTIDES ORIGINATING TOGETHER IN NEURONES OF THE TERMINAL ABDOMINAL GANGLION
}

\author{
HEINRICH DIRCKSEN, SIEGWARD BURDZIK, ARNOLD SAUTER AND RAINER KELLER* \\ Institut für Zoophysiologie, Rheinische Friedrich-Wilhelms-Universität Bonn, D-53115 Bonn, Germany \\ *Author for correspondence and present address: Institut für Zoophysiologie, Universität Bonn, Endenicher Allee 11-13, D-53115 Bonn, \\ Germany (e-mail: Keller@uni-bonn.de)
}

Accepted 23 June; published on WWW 22 August 2000

\begin{abstract}
Summary
The tridecapeptides $\mathbf{A s n}^{13}$-orcokinin and $\mathrm{Val}^{13}$ orcokinin, two known members of the orcokinin neuropeptide family native to crustaceans, and a novel octapeptide, orcomyotropin, FDAFTTGFamide, have been identified from extracts of hindguts of the crayfish Orconectes limosus using an isolated hindgut contractility bioassay, high-performance liquid chromatography, microsequencing and mass spectrometry. All three peptides display strong inotropic actions on crayfish hindguts. Orcomyotropin showed higher potency than the two orcokinins. Threshold concentration was approximately $5 \times 10^{-12} \mathrm{moll}^{-1}$ versus $10^{-10} \mathrm{moll}^{-1}$ for the two orcokinins. An approximately fivefold increase in contraction amplitude was observed with $10^{-9} \mathrm{moll}^{-1}$ orcomyotropin and $10^{-7} \mathrm{moll}^{-1}$ of the orcokinins. Asn ${ }^{13}$. and $\mathrm{Val}^{13}$-orcokinin did not differ significantly with regard

to their biological effects. Semi-isolated crayfish hearts and locust oviducts did not respond to the three peptides. Immunocytochemistry using antisera against Asn ${ }^{13}$. orcokinin and orcomyotropin showed that these neuropeptides are co-localized in approximately 80-90 neurones of the terminal abdominal ganglion that have been shown to innervate the entire hindgut muscularis via the intestinal nerve. The neurones form elaborate terminal branches preferentially on longitudinal hindgut muscles. Orcomyotropin is a novel crustacean member of the GF-amide family of myotropic and/or allatotropic neuropeptides from annelids, molluses and insects.

Key words: crustacean, neuropeptide, hindgut, bioassay, orcomyotropin, orcokinin, abdominal ganglion, immunocytochemistry, crayfish, Orconectes limosus.
\end{abstract}

\section{Introduction}

In arthropods, particularly insects and crustaceans, a large number of peptides have been identified because of their effect on visceral muscles, e.g. the heart and hindgut. The in vitro hindgut contraction assay has proved to be a particularly simple and efficient method for the detection of active peptides, mostly in extracts from the nervous system. Hence, these substances are termed myotropic peptides. However, this designation should not obscure the idea that many of these peptides are of broader physiological significance, e.g. as neuromodulators and as circulating hormones (Gäde et al., 1997; Gäde, 1997; Schoofs et al., 1997; Veelaert et al., 1998).

In crustaceans, approximately 40 different myotropic neuropeptides have been described. Many of them are members of peptide families that have been established by previous research on other invertebrates, e.g. insects, which are presently considered by several authors to be the closest relations of crustaceans (Averof and Akam, 1995; Friedrich and Tautz, 1995). As members of the RF-amide superfamily
(Price and Greenberg, 1989), nine different peptides have been identified in decapods (Trimmer et al., 1987; Krajniak, 1991; Mercier et al., 1993; Sithigorngul et al., 1998). They all belong to the FLRF-amide rather than the FMRF-amide type. Interestingly, none of them is identical to any of the members of the RF-amide superfamily known from other invertebrates. Other members of established families are two tachykininrelated peptides, which were identified from the nervous system of Cancer borealis (Christie et al., 1997), and two kinin-related peptides, which were identified from the nervous system of Penaeus vannamei (Nieto et al., 1998).

Recently, no less than 20 neuropeptides belonging to the allatostatin superfamily were identified from the thoracic ganglia of the shore crab Carcinus maenas (Duve et al., 1997), which is more than has ever been found in a single species of insect. In Orconectes limosus, there is also evidence of a large number of allatostatin-like peptides, three of which have been fully characterised (Dircksen et al., 


\section{H. DIRCKSEN AND OTHERS}

1999). Interestingly, none of the crustacean allatostatins is identical to any of the more than 50 known insect allatostatins (Duve et al., 1998; Weaver et al., 1998). The activity of the allatostatins in the hindgut bioassay is inhibitory, and they have also been shown to act as inhibitory neuroactive substances in the stomatogastric ganglion (Skiebe and Schneider, 1994; Dircksen et al., 1999). Two other welldocumented myoactive peptides are proctolin and crustacean cardioactive peptide (CCAP) (for reviews, see Keller, 1992; Dircksen, 1994). Both show excitatory activity on the crayfish hindgut (Stangier, 1992; Mercier et al., 1997).

The orcokinins (OKs) constitute a novel peptide family which is known only from crustaceans. We identified the original orcokinin, NFDEIDRSGFGFN (=Asn $\left.{ }^{13}-\mathrm{OK}\right)$, from the nervous system of the crayfish $O$. limosus (Stangier et al., 1992) and, subsequently, the analogues Ser ${ }^{9}-O K \mathrm{Ala}^{13}-\mathrm{OK}$ and $\mathrm{Val}^{13}$-OK from the thoracic ganglia of the shore crab $C$. maenas (Bungart et al., 1995a). Since the hindgut of $O$. limosus was found to have a high content of OK-immunoreactive material (Bungart et al., 1994), an attempt was made to determine whether this material was identical to the OK from the nervous system and whether other OK analogues existed in the hindgut. During the course of this work, a novel hindgutcontracting peptide, which we named orcomyotropin (OMT), was found. The isolation and characterization of this peptide, including some results on the immunocytochemical mapping of OMT-positive neurones in the nervous system of $O$. limosus, are described. In addition, we confirmed the occurrence of authentic $\mathrm{OK}$ in the hindgut and identified $\mathrm{Val}^{13}-\mathrm{OK}$ which, until now, has been found only in $C$. maenas.

\section{Materials and methods \\ Animals and tissue extraction}

American crayfish, Orconectes limosus (Rafinesque, 1871), came from the Havel River in Berlin and were purchased from a commercial fisherman. They were kept in running tap water at $12{ }^{\circ} \mathrm{C}$ and fed commercial cat food pellets once a week. Shore crabs, Carcinus maenas, were obtained from the Netherlands Instituut voor Onderzoek der Zee, Texel, or the Centrum voor Estuarine en Marine Oekologie, Yerseke, The Netherlands, and were kept in artificial sea water and fed as for the crayfish. Locusts, Locusta migratoria, came from a commercial breeder and were kept at $30^{\circ} \mathrm{C}$ and fed oats and fresh grass.

The crayfish (mass range 15-30 g) were used irrespective of sex. Prior to dissection, they were chilled to $0^{\circ} \mathrm{C}$ in a mixture of ice and water. Hindguts were dissected under chilled saline (Van Harreveld, 1936), rinsed in extraction medium to remove faeces, and immediately placed in extraction medium [5\% formic acid, $1 \%$ trifluoracetic acid (TFA), $1 \% \mathrm{NaCl}$ in $1 \mathrm{moll}^{-1}$ $\mathrm{HCl}$; Bennett et al., 1974], in which they were stored at $-20^{\circ} \mathrm{C}$. Approximately 500 hindguts were homogenised in $100 \mathrm{ml}$ of extraction medium by sonication on ice (10 times for $30 \mathrm{~s})$. The homogenate was stirred for $24 \mathrm{~h}$ at $4{ }^{\circ} \mathrm{C}$. After centrifugation at $30000 \mathrm{~g}$ for $60 \mathrm{~min}$, the pellet was re-extracted twice, first with
$50 \mathrm{ml}$ and then with $25 \mathrm{ml}$ of extraction medium. The combined supernatants were stored at $-20^{\circ} \mathrm{C}$.

\section{Sep-Pak prepurification}

A column of three serially connected Sep-Pak C-18 cartridges (Millipore-Waters) was conditioned first with $15 \mathrm{ml}$ of $60 \% \mathrm{CH}_{3} \mathrm{CN} / 0.11 \%$ TFA and then with $15 \mathrm{ml}$ of $0.11 \%$ TFA. The crude extract was passed through the cartridges at a flow rate of $1.5 \mathrm{ml} \mathrm{min}-1$. After rinsing with $15 \mathrm{ml}$ of $0.11 \%$ TFA, adsorbed material was eluted in three steps with $8 \mathrm{ml}$ each of $20 \%, 36 \%$ and $60 \% \mathrm{CH}_{3} \mathrm{CN} / 0.11 \%$ TFA. The three fractions were concentrated in a SpeedVac concentrator (Savant) and stored at $-20^{\circ} \mathrm{C}$.

\section{Chromatography}

All separations were carried out by reversed-phase highperformance liquid chromatography (HPLC) on an HPLC system consisting of two type 510 pumps, a model 680 solvent programmer, a U6K injector and a Lambda Max 481 ultraviolet detector (Millipore-Waters). Chromatograms were recorded with a Waters 240 data module, and a fraction collector (LKB 21111 Multivac) was used for eluate fractionation. As solvents, $0.11 \%$ TFA in $\mathrm{H}_{2} \mathrm{O}$ (solvent A) and $60 \% \mathrm{CH}_{3} \mathrm{CN}(\mathrm{MeCN})$ in $0.10 \% \mathrm{TFA} / \mathrm{H}_{2} \mathrm{O}$ (solvent $\mathrm{B}$ ) were used. The following columns were used: Phenyl RCM, $8 \mathrm{~mm} \times 100 \mathrm{~mm}$, and Phenyl $\mu$-Bondapak, $3.9 \mathrm{~mm} \times 300 \mathrm{~mm}$ (Millipore-Waters); Bakerbond WP C8, $3.9 \mathrm{~mm} \times 250 \mathrm{~mm}$, and Bakerbond WP C18, $3.9 \mathrm{~mm} \times 250 \mathrm{~mm}$ (Baker); Alltech C18, $3 \mu, 3.9 \mathrm{~mm} \times 150 \mathrm{~mm}$ (Alltech). The column types used for individual chromatographic separations and the solvent gradients employed are detailed in the figure legends.

\section{Bioassays}

Isolated hindguts of $O$. limosus were mounted in a vertical Perspex chamber $(1.2 \mathrm{ml})$ by connecting the posterior end with cotton thread to a hook in the bottom of the chamber and the anterior end to a force transducer (Grass FT03). The chamber was perfused with saline at room temperature $\left(20^{\circ} \mathrm{C}\right)$. Before application of samples or control saline, the chamber was drained and refilled immediately with test solution. Alternatively, solutions were continuously applied with a peristaltic pump at a flow rate of $2 \mathrm{ml} \mathrm{min}^{-1}$ to avoid the artificial stretch responses that were sometimes caused by withdrawal of the medium. A preload of approximately $100 \mathrm{mg}$ was applied to the hindguts, and contractions were recorded with a preamplifier (Grass 7 P 122 D), equipped with a chart recorder. The same procedure was used for hindguts of $C$. maenas and L. migratoria and for the oviduct of the latter species. Salines used were Van Harreveld's for $O$. limosus (Van Harreveld, 1936), Pantin's for C. maenas (Pantin, 1934) and Locusta saline (Lange, 1987).

Isolated hearts of $O$. limosus and $C$. maenas were prepared by removal of a piece of the cardiac region of the carapace with the heart attached by the dorsal ligaments, which were left intact. The exoskeletal fragment was trimmed to an appropriate size and connected to the hook in the chamber described above. 
The heart muscle was connected to the force transducer by a small hook fashioned from an insect pin. For bioassays on semi-isolated hearts, a window was cut in the dorsal cardiac carapace region, the dorsal ligaments were transected and the exposed heart, which was continuously superfused with saline, was hooked to the force transducer. When the contraction rate had stabilised, test solutions were applied directly.

\section{Amino acid analysis}

Peptide samples (30-100 pmol) were hydrolysed for $60 \mathrm{~min}$ at $150^{\circ} \mathrm{C}$ in $30 \mu \mathrm{l}$ of $5.6 \mathrm{moll}^{-1} \mathrm{HCl}$ (Sigma, constant boiling) in evacuated and sealed ampoules and analysed in an automated amino acid analyser (Biotronik LC 5000) with orthophthaldialdehyde (OPA) post-column derivatisation.

\section{Peptide sequencing}

The amino acid sequences of OK and OMT were determined with an automated gas-phase sequencer (Applied Biosystems 477 A) equipped with an on-line phenylthiohydantoin-amino acid (PTH) analyser (Applied Biosystems 120). Val ${ }^{13}$-OK was sequenced by fast atom bombardment (FAB)/tandem mass spectroscopy (FAB-MS), using a TSQ-70 triple-quadrupole instrument (Finnigan-MAT, San Jose, California, USA) equipped with a $15 \mathrm{keV}$ caesium source (Antek, Palo Alto, California, USA). Approximately $100 \mathrm{pmol}$ of purified peptide was taken up in $0.1 \%$ TFA and applied in a thioglycerol film on the sample surface of the mass spectrometer. Ionisation was achieved with a Cs beam of $6-8 \mathrm{keV}$. The sequence was deduced from analysis of the collision-activated dissociation (CAD) spectra (Hunt et al., 1986, 1989; Biemann, 1992). Methyl ester formation was carried out by incubation of peptide samples in $2 \mathrm{moll}^{-1} \mathrm{HCl}$ in methanol (Kuster et al., 1991). The sequence of orcomyotropin has been deposited in the Swiss-Prot. protein sequence data base under accession number P82455 OMT (6.04.2000).

\section{Peptide synthesis}

Fluorenyl methoxy carbonyl (Fmoc) solid-phase peptide synthesis was carried out on a manual peptide synthesiser (LKB Biolynx 4175) controlled by a personal computer and connected to a spectrophotometer. In a previous paper, in which we reported the synthesis of OK, the procedure was described in detail (Bungart et al., 1995b). In the present study, $\mathrm{Val}^{13}$-OK was synthesised according to the same procedure. Orcomyotropin was synthesised both as its C-terminal free acid and in amidated form using Novasyn A and Novasyn PR resins, respectively, according to established procedures (Atherton and Sheppard, 1989). Both resins and Fmoc amino acids were purchased from Novabiochem (Bad Soden, Germany). The synthetic peptides were purified by HPLC.

\section{Immunocytochemistry}

Terminal (sixth) abdominal ganglia and hindguts were fixed overnight in a phosphate-buffered paraformaldehyde/picric acid mixture (Stefanini et al., 1967), and immunocytochemical staining was performed using established peroxidase/ antiperoxidase methods on whole mounts or Paraplast sections, as described previously (Dircksen et al., 1991) except that $0.1 \mathrm{moll}^{-1}$ Tris-HCl-buffered saline containing $0.5 \%$ Triton X100 (TBTX) was used instead of phosphate-buffered salines. Antisera against Asn ${ }^{13}$-OK (Bungart et al., 1994) were used at a final dilution of 1:5000 in TBTX. For OMT, novel antisera were produced in three New Zealand White rabbits by sub- and intracutaneous injections of synthetic OMT covalently coupled via carbodiimide to bovine thyroglobulin following the method described by Dircksen and Keller (1988). The antisera had slightly different titres, but all stained essentially the same structures. For most preparations, anti-OMT code T68B1/1 was used at a final dilution of 1:1000 in TBTX. Preparations were viewed and photographed using bright-field or Nomarski optics on a Zeiss Axioskop microscope. Preabsorption controls were performed on Paraplast sections. In the case of the anti-Asn ${ }^{13}$ OK and the anti-OMT sera, 50 or $100 \mathrm{nmol}$ of synthetic Asn ${ }^{13}$. OK or 20,50 or $100 \mathrm{nmol}$ of synthetic $\mathrm{Val}^{13}-\mathrm{OK}$ or OMT, calculated per microlitre of the corresponding antiserum was added to the final antiserum dilutions $24 \mathrm{~h}$ prior to the start of the staining procedure. Whereas $\mathrm{Val}^{13}-\mathrm{OK}$ strongly decreased the staining intensity of anti-Asn ${ }^{13}-\mathrm{OK}$ at $20 \mathrm{nmol} \mu \mathrm{l}^{-1}$ antiserum, it did not block the staining completely, even at $100 \mathrm{nmol} \mu \mathrm{l}^{-1}$ antiserum, but $50 \mathrm{nmol}$ of $\mathrm{Asn}^{13}$-OK (the original antigen) completely abolished immunostaining. In the case of the anti-OMT serum, $20 \mathrm{nmol} \mathrm{OMT} \mu \mathrm{l}^{-1}$ antiserum was sufficient to block immunostaining completely.

\section{Results Isolation of OMT and Asn $n^{13}-O K$}

The crude hindgut extract had a very potent contractionenhancing activity in the $O$. limosus hindgut assay. After stepwise Sep-Pak pre-purification, the myotropic activity was almost exclusively recovered in the $36 \% \mathrm{CH}_{3} \mathrm{CN} / 0.1 \%$ TFA eluate. HPLC of this fraction on a high-capacity column yielded four distinct bioactive zones (I-IV, Fig. 1A). Rechromatography of the combined fractions comprising zone I on a different column resulted in a further enrichment of the active material (Fig. 1B). After a third chromatographic step on another column, the active material was separated into two peaks (a and b, Fig. 1C). Peak a was subjected to two further successive rechromatographies, the second of which resulted in a single, symmetrical bioactive peak (Fig. 1D,E). This peak turned out to be the novel myotropic peptide, OMT. Peak b from Fig. 1C was rechromatographed with a non-linear gradient (Fig. 2A), resulting in two peaks, only one of which showed bioactivity. This peak was rechromatographed with a linear gradient (Fig. 2B) and, from the retention time, it was suspected that it might contain OK; when a mixture of the unknown peptide and synthetic OK was subjected to chromatography, it did indeed appear as a single peak (Fig. 2C). Amino acid analysis of two samples (approximately $25 \mathrm{pmol}$ each) yielded the following residues: Asx (87 pmol), Ser $(27 \mathrm{pmol})$, Glx $(33 \mathrm{pmol})$, Gly $(57 \mathrm{pmol})$, Ile $(31 \mathrm{pmol})$, Phe $(78 \mathrm{pmol})$ and Arg $(28 \mathrm{pmol})$. This was in good agreement with the composition of an identically treated sample of synthetic OK. 

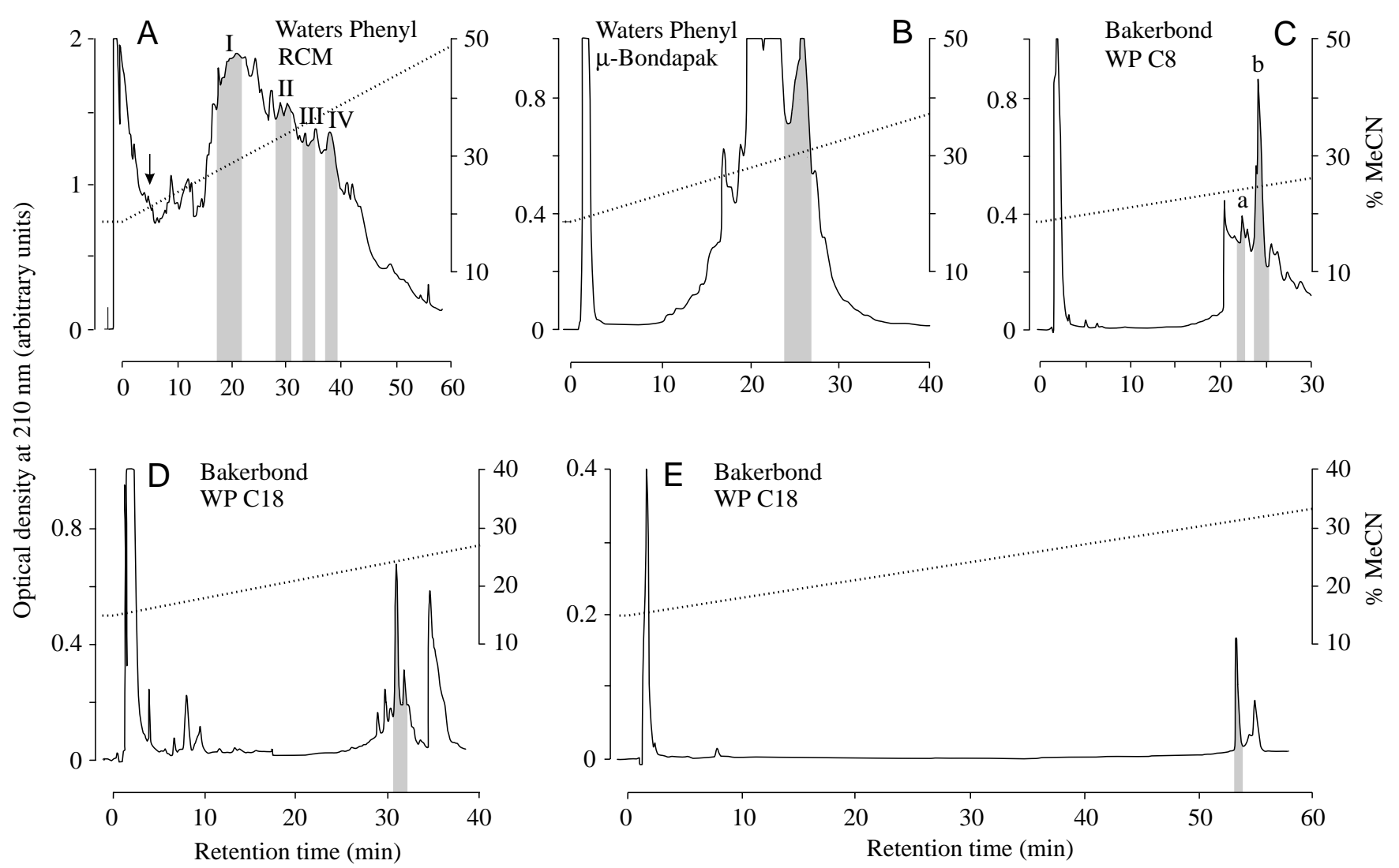

Fig. 1. Reversed-phase high-performance liquid chromatography (HPLC) purification of bioactive fractions (stippled areas) from extracts of hindguts of the crayfish Orconectes limosus and isolation of orcomyotropin (OMT). (A) First-step HPLC of the $36 \%$ MeCN Sep-Pak fraction (130 hindgut equivalents) showing four hindgut-bioactive zones (I-IV) of eluates collected automatically (1 min per fraction; linear gradient $18 \%$ to $48 \% \mathrm{MeCN}$ in $60 \mathrm{~min}$ ); the arrow points to the retention time of synthetic proctolin. (B) Second-step HPLC of zone I in A (linear gradient $18 \%$ to $39 \% \mathrm{MeCN}$ in $45 \mathrm{~min}$ ) showing myotropic activity in fractions $24-27$. (C) Third-step HPLC of the bioactive zone in B separated into two bioactive zones (a and b; linear gradient $18 \%$ to $30 \% \mathrm{MeCN}$ in $45 \mathrm{~min}$; only the relevant part of the chromatogram is shown). (D) Fourth-step HPLC (linear gradient $15 \%$ to $30 \% \mathrm{MeCN}$ in $50 \mathrm{~min}$ ) of the first bioactive zone (a; retention time $22-23 \mathrm{~min}$ ) in C (250 hindgut equivalents) yielding a bioactive area with two peak fractions, which were finally separated in the fifth HPLC step (E), yielding a distinct homogeneous and hindgut-bioactive peak fraction containing pure orcomyotropin.

Finally, Edman sequencing confirmed the sequence of OK as: NFDEIDRSGFGFN-OH.

\section{Sequence analysis of OMT}

The material obtained as a single, symmetrical peak (Fig. 1E) was first subjected to amino acid analysis. Analysis of approximately $60 \mathrm{pmol}$ yielded the following amino acids (amounts and deduced number of residues in parentheses): Asx (46 pmol; 1), Thr (94 pmol; 2), Ser (10 pmol; 0.15, considered an impurity), Gly (64 pmol; 1), Ala (58 pmol; 1) and Phe (164 pmol; 3). Determination of the mass by FAB-MS gave a value of $904.8\left(\mathrm{M}+\mathrm{H}^{+}\right)$, which suggested, in agreement with the calculated value from the amino acid composition, an octapeptide. To determine whether the $\mathrm{C}$ terminus was a free carboxyl or amide group, the peptide was methylated and again subjected to FAB-MS. A mass of $918.5\left(\mathrm{M}+\mathrm{H}^{+}\right)$was found, demonstrating the presence of only one carboxyl group. Since Asp was detected as residue 2 (following Phe) after two cycles of manual sequencing, and since no other amino acid with a carboxyl side chain was present, this result clearly suggested the presence of a C-terminal amide group. Automated sequencing of two samples of approximately 300 and $450 \mathrm{pmol}$ yielded the sequence of OMT: FDAFTTGFamide.

\section{Synthesis of OMT}

To confirm the sequence and to obtain sufficient material for bioassays and antibody production, $\mathrm{OMT}-\mathrm{NH}_{2}$ and $\mathrm{OMT}-\mathrm{OH}$ were synthesised by Fmoc solid-phase chemistry. Native OMT and synthetic OMT eluted with identical retention times in HPLC (Fig. 3A,C), while OMT-OH eluted at a higher retention time (Fig. 3B). A mixture of native OMT, synthetic OMT- $\mathrm{NH}_{2}$ and OMT-OH showed precise co-elution of the two former substances as a single peak and clear separation from OMT$\mathrm{OH}$ (Fig. 3D). This confirmed the existence of a C-terminal amide group in the native OMT.

\section{Identification of $\mathrm{Val}^{13}$-OK}

The material of zone II in Fig. 1A was subjected to a first rechromatography step on a Waters Phenyl $\mu$-Bondapak column. This separated a narrow active zone from considerable 

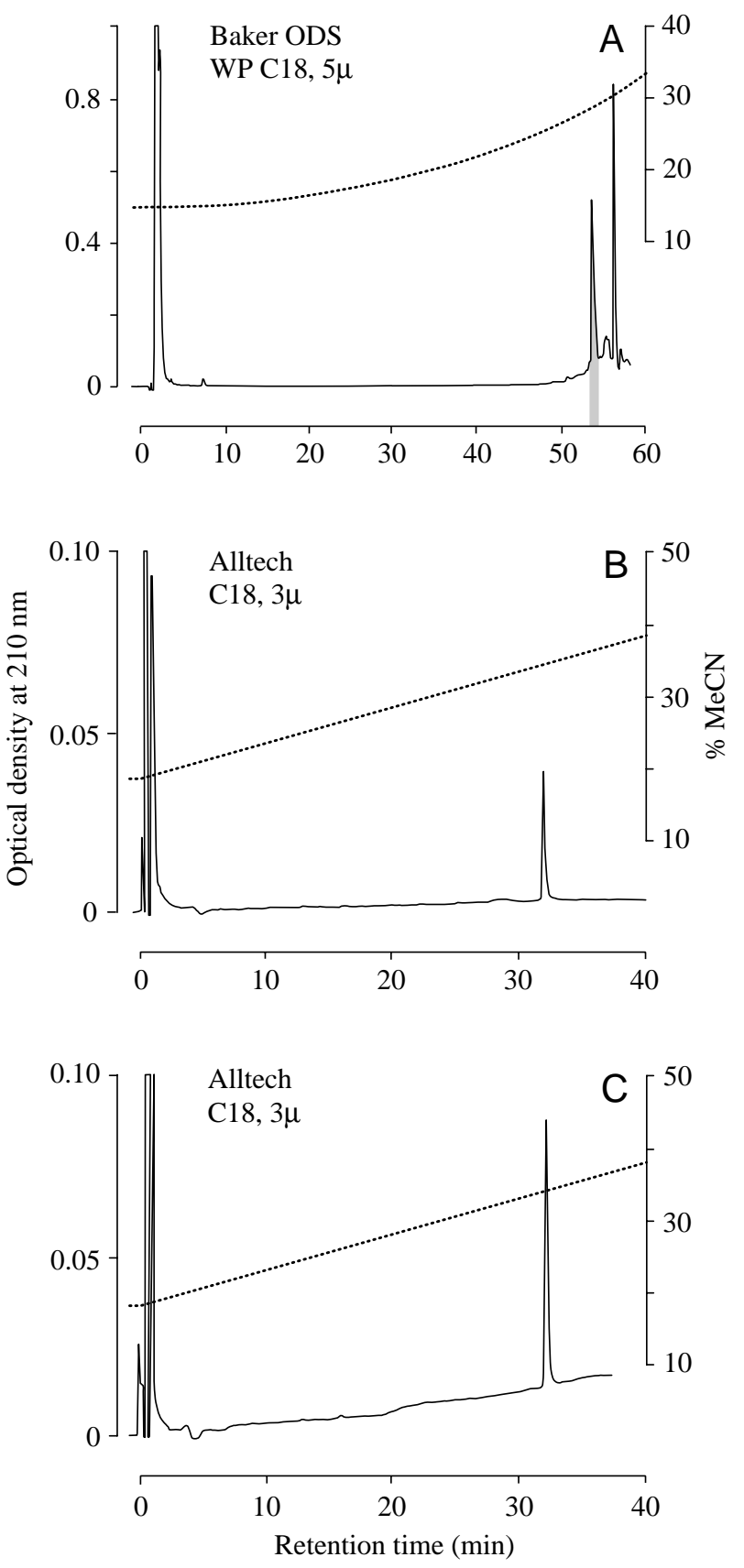

Fig. 2. Purification of $\mathrm{Asn}^{13}$-orcokinin (Asn ${ }^{13}-\mathrm{OK}$ ). (A) Rechromatography of fractions making up the second bioactive zone b in Fig. 1C (retention times 24-25.5 min; 250 hindgut equivalents; concave gradient $15 \%$ to $33 \% \mathrm{MeCN}$, curve no. 8 on Waters gradient controller), yielding one single hindgut-bioactive peak fraction (B) (linear gradient $18 \%$ to $46 \%$ $\mathrm{MeCN}$ in $60 \mathrm{~min}$; retention time $32.5 \mathrm{~min}$ ). Spiking of a sample of this fraction (approximately $500 \mathrm{pmol})$ with $1 \mu \mathrm{g}(660 \mathrm{pmol})$ of synthetic $\mathrm{Asn}^{13}$-OK and rechromatography (gradient $18 \%$ to $46 \%$ $\mathrm{MeCN}$ in $60 \mathrm{~min}$ ) resulted in a single peak (C).

amounts of inactive material (Fig. 4A). After two further chromatographic separations, a single peak was obtained (Fig. 4B,C). This peak, which seemed to be homogeneous, did,
Table 1. Residual masses (R) of $b$ - and $y$-ions after tandem mass spectrometry of native ( $b$ - and $y$-ions) and methylated $\mathrm{Val}^{13}-\mathrm{OK}(\mathrm{b}$ - and $y$-ionsmeth $)$

\begin{tabular}{lccccc}
\hline$R$ & b-ion & b-ion $_{\text {meth }}$ & $R$ & y-ion & y-ion \\
\hline 1 & ND & ND & 13 & ND & ND \\
$1-2$ & 261.6 & 259.7 & $13-12$ & ND & ND \\
$1-3$ & 375.0 & 389.4 & $13-11$ & 323.5 & ND \\
$1-4$ & $504.5^{*}$ & 533.0 & $13-10$ & 470.6 & ND \\
$1-5$ & $618.9^{*}$ & 645.1 & $13-9$ & 525.0 & 540.5 \\
$1-6$ & $733.5^{*}$ & 775.0 & $13-8$ & 612.5 & 627.5 \\
$1-7$ & 889.5 & 931.1 & $13-7$ & ND & 781.8 \\
$1-8$ & 976.5 & 1018.1 & $13-6$ & ND & 914.0 \\
$1-9$ & 1033.5 & 1075.0 & $13-5$ & 995.6 & 1024.7 \\
$1-10$ & 1180.1 & 1222.0 & $13-4$ & ND & 1168.6 \\
$1-11$ & 1238.2 & 1279.9 & $13-3$ & 1240.2 & 1298.5 \\
$1-12$ & 1384.6 & 1426.5 & $13-2$ & ND & 1444.0 \\
$1-13$ & 1501.7 & 1558.1 & $13-1$ & 1501.7 & 1558.1
\end{tabular}

ND, not detected.

*Asterisks indicate masses of b-ions not unambiguously attributable to a particular amino acid.

however, yield two masses, 1502.7 $\mathrm{Da}\left(\mathrm{M}+\mathrm{H}^{+}\right)$and $1371.2 \mathrm{Da}$ $\left(\mathrm{M}+\mathrm{H}^{+}\right)$, when subjected to FAB-MS.

In a further rechromatography on a Bakerbond WP C18 column and with a step gradient, the two substances could be separated (Fig. 4D). The observed mass was $1502.7 \mathrm{Da}$, which was very close to the masses of $\mathrm{OK}$ analogues previously identified from the thoracic ganglion of $C$. maenas (Bungart et al., 1995a), so this peak was likely to be a member of this peptide family. Synthetic OK (mass 1517.5 Da) was therefore included in the separation. OK (retention time $17 \mathrm{~min}$ ) was clearly separated from a minor (retention time $21 \mathrm{~min}$ ) and a larger peak (retention time $23 \mathrm{~min}$ ) fraction, only the latter containing biological activity (Fig. 4D). Amino acid analysis of this peak fraction and, for comparison, of synthetic OK (approximately $50 \mathrm{pmol}$ each) showed an identical number of 13 residues. In the unknown substance, however, one Asx was missing, and one Val was present instead. For sequence determination, approximately $300 \mathrm{pmol}$ was analysed by tandem-MS. The CAD spectrum yielded a set of b-ions, in which only the mass-signal of the N-terminal residue was missing. The set of corresponding $\mathrm{y}$-ions was incomplete with regard to the C-terminal low-mass fragments. Using a combination of both sets of data, however, the mass of all residues was determined unambiguously (Table 1).

The tandem-MS-determined mass of $1501.7 \mathrm{Da}\left(\mathrm{M}+\mathrm{H}^{+}\right)$of the whole peptide confirmed that the FAB-MS-determined value of $1502.7 \mathrm{Da}\left(\mathrm{M}+\mathrm{H}^{+}\right)$was accurate. The mass of the $\mathrm{b}-$ ion 1-12 of the peptide was identical to that of the b-ion 1-12 of $\mathrm{OK}$, whereas the mass of the remaining residue was lower by $15 \mathrm{Da}$. The y-ion $13-1$ of the peptide was lower by $15 \mathrm{Da}$ compared with the y-ion 13-1 of OK, proving that the Val residue $(99.14 \mathrm{Da})$ of the peptide was in position 13 instead of Asn $(114.11 \mathrm{Da})$ in OK. Unambiguous identification of residues $1,3,4,6$ and 13 as either $\mathrm{N}$ or $\mathrm{D}, \mathrm{Q}$ or $\mathrm{E}$ - and $\mathrm{V}-\mathrm{OH}$ 


\section{H. DIRCKSEN AND OTHERS}

Fig. 3. Reversed-phase high-performance liquid chromatography (HPLC) (linear gradient $18 \%$ to $30 \% \mathrm{MeCN}$ in $30 \mathrm{~min}$ ) of (A) synthetic orcomyotropin (OMT- $\mathrm{NH}_{2}$; $200 \mathrm{pmol}$ ) and (B) its non-amidated synthetic analogue (OMT-OH) showing the different retention times of the two forms under identical conditions. (C) Native orcomyotropin (OMT) eluting at exactly the same retention time as synthetic OMT in A. (D) Cochromatography of a mixture of native OMT, synthetic OMT-NH 2 and OMT-OH. The retention time of OMT- $\mathrm{NH}_{2}$ is approximately $3.5 \mathrm{~min}$ shorter than that of $\mathrm{OMT}-\mathrm{OH}$.
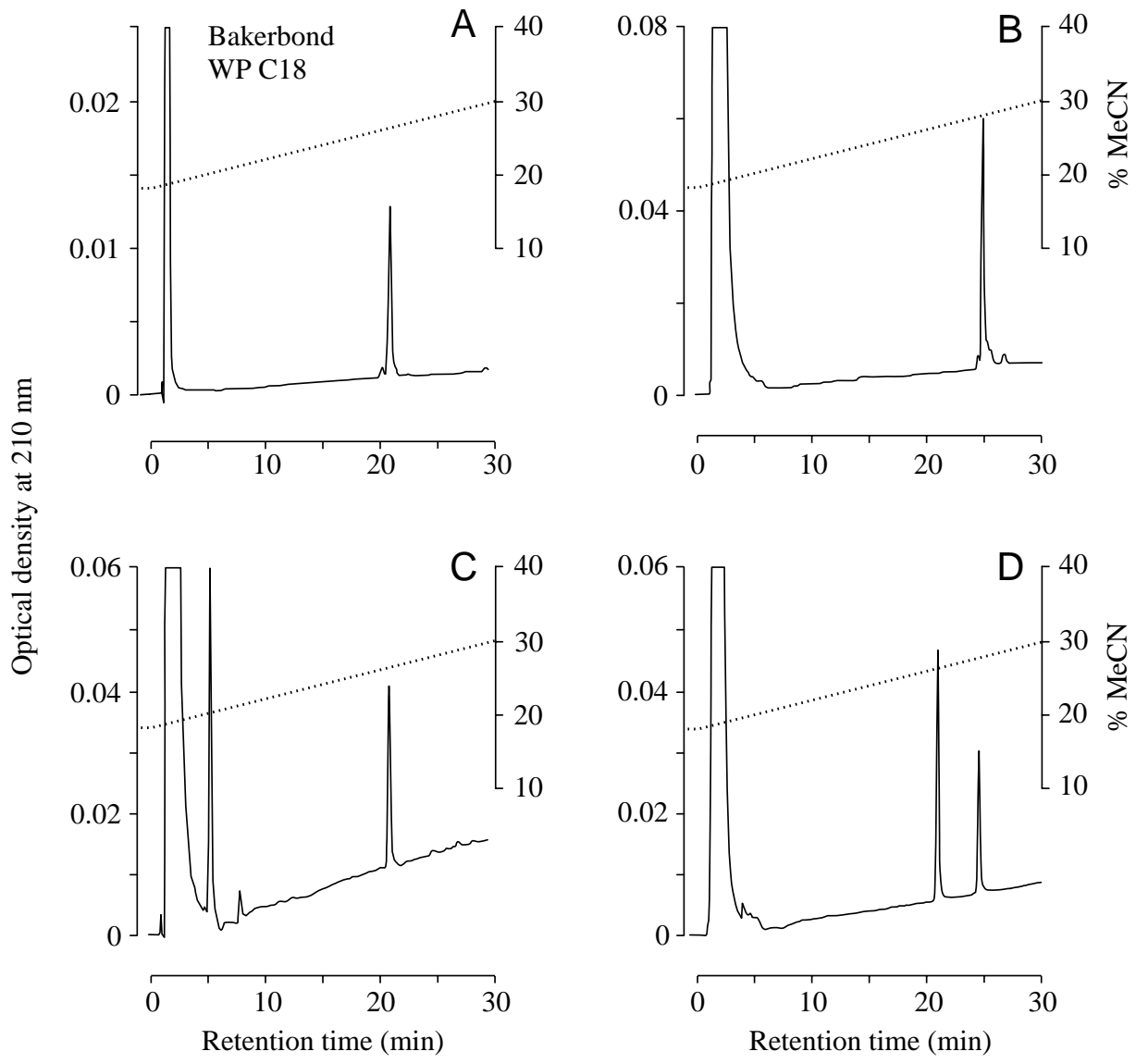

or $\mathrm{V}-\mathrm{NH}_{2}$, respectively, was not directly possible because of the small mass differences of 1-3 Da. To resolve this, methylation was carried out, and the numbers and positions of methylation sites were analysed (Table 1). The results assigned $\mathrm{N}$ to position 1, D to position 3 and 6 , E to position 4 and $\mathrm{V}$ $\mathrm{OH}$ to position 13, giving the sequence NFDEIDRSGFGFV$\mathrm{OH}$ (Val $\left.{ }^{13}-\mathrm{OK}\right)$. This peptide was synthesised by Fmoc chemistry, and identity with the native peptide was ascertained by HPLC of a mixture of the two, which gave a single peak (data not shown).

\section{Biological activity of $\mathrm{Val}^{13}{ }_{-} \mathrm{OK}$ and $\mathrm{OMT}$}

Crayfish hindgut

Most isolated hindguts of $O$. limosus showed spontaneous contractions, whose frequency and amplitude were enhanced by both peptides in a concentration-dependent manner (Figs 5, 6). Preparations that did not display spontaneous contractions were activated by OMT and $\mathrm{Val}^{13}$-OK (Fig. 5A, 6A). The synthetic and native peptides did not differ in their biological activities.

The threshold concentration for $\mathrm{Val}^{13}{ }^{13} \mathrm{OK}$ was approximately $10^{-10} \mathrm{moll}^{-1}$, and a concentration of $2 \times$ $10^{-9} \mathrm{moll}^{-1}$ caused, on the average, a $100 \%$ elevation of contraction amplitude. Higher concentrations, e.g. $10^{-6} \mathrm{moll}^{-1}$, tended to result in an enhanced tonic component (Fig. 6C). For OMT, the threshold was approximately $5 \times 10^{-12} \mathrm{moll}^{-1}$, and a $100 \%$ increase of the amplitude was seen at approximately
$5 \times 10^{-11} \mathrm{moll}^{-1}$. At a concentration of approximately $10^{-7} \mathrm{moll}^{-1}$, a tonic component appeared, which increased with higher concentrations. The two peptides differed not only in potency, OMT being the more active, but also in response time. This was $1-3 \mathrm{~min}$ for $\mathrm{Val}^{13}-\mathrm{OK}$, depending on the concentration, whereas hindguts responded to OMT within seconds of application, even at low concentrations. Fig. 7 shows dose-response curves for the inotropic effects of OMT, OMT-OH and $\mathrm{Val}^{13}-\mathrm{OK}$, demonstrating the high potency of OMT and the lower potency of $\mathrm{Val}^{13}-\mathrm{OK}$ and of the nonamidated synthetic analogue of OMT.

\section{Crustacean hearts}

We observed no significant effect of either $\mathrm{Val}^{13}-\mathrm{OK}$ or OMT on the rate and/or amplitude of contraction of isolated and semi-isolated in situ heart preparations of O. limosus and C. maenas ( $N=3$ for each species).

\section{Locust hindgut and oviduct}

Even at concentrations of up to $10^{-7} \mathrm{moll}^{-1}$, neither tissue responded to OMT or $\mathrm{Val}^{13}{ }_{-} \mathrm{OK}$. As a control, equimolar or lower concentrations of proctolin and CCAP were applied to the same preparations and were found to elicit strong responses $(N=2$; data not shown).

\section{Immunocytochemistry}

The terminal (sixth) abdominal ganglion of crayfish contains 
Fig. 4. Purification of $\mathrm{Val}^{13}$-orcokinin (Val $\left.{ }^{13}-\mathrm{OK}\right)$. (A) Rechromatography of the hindgut-bioactive fractions from zone II in Fig. 1A (gradient 18\% to $48 \% \mathrm{MeCN}$ in $60 \mathrm{~min}$; only the relevant parts of the chromatogram are shown; 250hindgut equivalents) showing hindgut-bioactive fractions (stippled area) at a retention time of 29.5-31 min. (B) Rechromatography of this zone on the C18 column (same gradient as in A); the stippled area shows bioactive fractions at a retention time of 29-32 min. (C) Further rechromatography of the material from the stippled zone using a linear step gradient $(18 \%$ to $27 \%$ $\mathrm{MeCN}$ in $10 \mathrm{~min}$ followed by $27 \%$ to $33 \% \mathrm{MeCN}$ in $45 \mathrm{~min}$ ). (D) Final rechromatography (linear step gradients $18 \%$ to $26.4 \% \mathrm{MeCN}$ in $10 \mathrm{~min}$ followed by $26.4 \%$ to $32.4 \%$ $\mathrm{MeCN}$ in $45 \mathrm{~min}$ ) of the single peak fraction shown in C. $\mathrm{Val}^{13}$-orcokinin elutes as the last peak separated from a small non-bioactive impurity (second peak). The first peak represents synthetic Asn ${ }^{13}$-orcokinin (approximately $2 \mu \mathrm{g}=1.32 \mathrm{nmol}$ ) that was added to the sample.

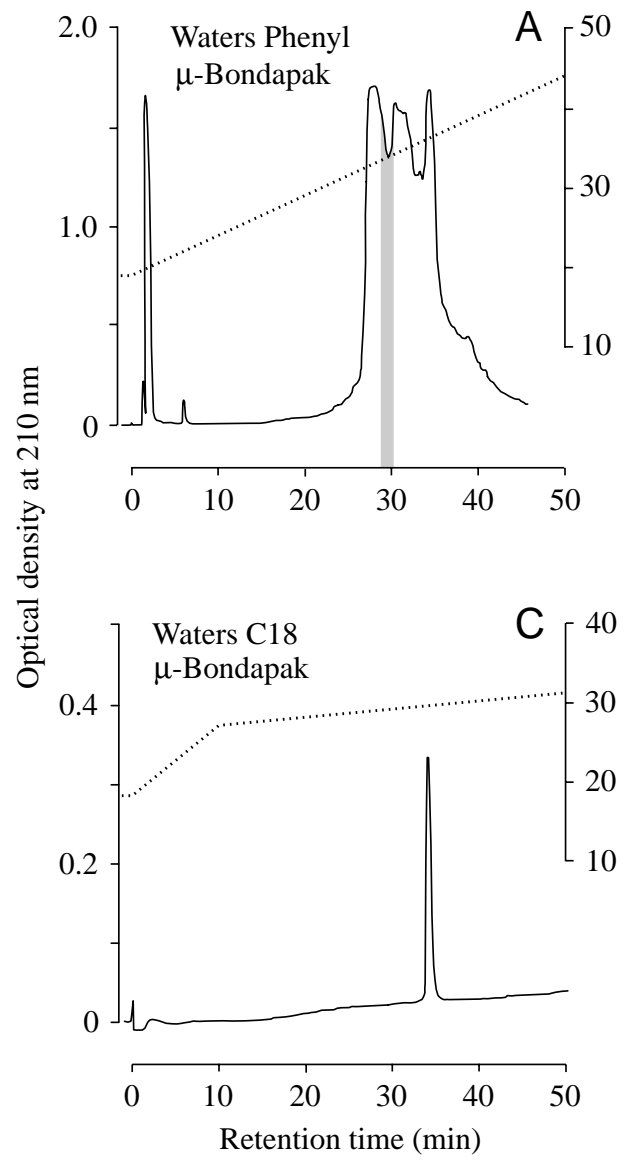

a cluster of approximately $80-90$ neurones $(25-30 \mu \mathrm{m}$ in diameter) with clearly co-localised OK- and OMTimmunoreactivity (Fig. 8A,B). The immunoreactivity is localised in the posterior median part of the ganglion, which innervates the entire hindgut via the nervus intestinalis (Keim, 1915; Orlov, 1926). This paired but fused nerve separates into two anterior branches and one posterior branch (nervi intestinales anterior and posterior; Keim, 1915). The OK/OMT-immunoreactive axons and fibres can be followed up to the ampullae of the stomach and down to the anus. Fibres branch off from these nerves along its length and terminate on the longitudinal hindgut musculature, forming elaborate varicosities and terminal arborizations. Few and less extensive terminals are also observed on the ring musculature (Fig. 8C,D).

\section{Discussion}

Orcokinin (OK), the prototype member of a novel family of myotropic peptides, was first identified from the nervous system of the crayfish Orconectes limosus (Stangier et al., 1992). Subsequently, we identified the analogues $\mathrm{Ser}^{9}{ }^{-}, \mathrm{Ala}^{13}{ }_{-}$ and $\mathrm{Val}^{13}$-OK from thoracic ganglia of the shore crab Carcinus maenas (Bungart et al., 1995a). Quantitative measurements of OK-like immunoreactivity in different parts of the crayfish nervous system and in the hindgut using enzyme-linked immunosorbent assay (ELISA) revealed the latter to contain the highest amounts (per organ) of OK-like immunoreactivity (Bungart et al., 1994). This prompted us to analyse the OKlike immunoreactive substances of the hindgut to determine whether (i) an OK identical to that occurring in the nervous system was present, and (ii) whether analogues such as those known from the nervous system of $C$. maenas could be identified. In the present study, we confirmed the existence of $\mathrm{OK}$ and further identified $\mathrm{Va}{ }^{13}-\mathrm{OK}$. It is possible that other OK analogues occur in the crayfish hindgut. As shown in Fig. 1A, there are two zones of myotropic activity (III, IV) after the first HPLC step of hindgut extract that we have not yet analysed. From the amino acid analyses, we estimate an OK content of $4 \mathrm{pmol}$ and a $\mathrm{Val}^{13}{ }^{13} \mathrm{OK}$ content of $0.7 \mathrm{pmol}$ per hindgut. In a previous study, we found a total of $55 \mathrm{pmol}$ of OK-equivalents per $O$. limosus hindgut using ELISA (Bungart et al., 1994). Therefore, even if there are considerable losses during the different HPLC steps, it seems possible that we have not yet detected all the OK-like peptides that may be present. However, the results provide sufficient evidence to conclude that particular $\mathrm{OK}$ analogues are not species-specific and that at least two, and probably more, members of the family occur in a single species.

In the course of this work on orcokinin, we discovered the novel, potent myotropic peptide OMT, with the amino acid sequence FDAFTTGFamide. A databank search (SwissProt, BLAST) did not reveal significant homology with any known peptide. However, the C-terminal XGFamide motif does occur 


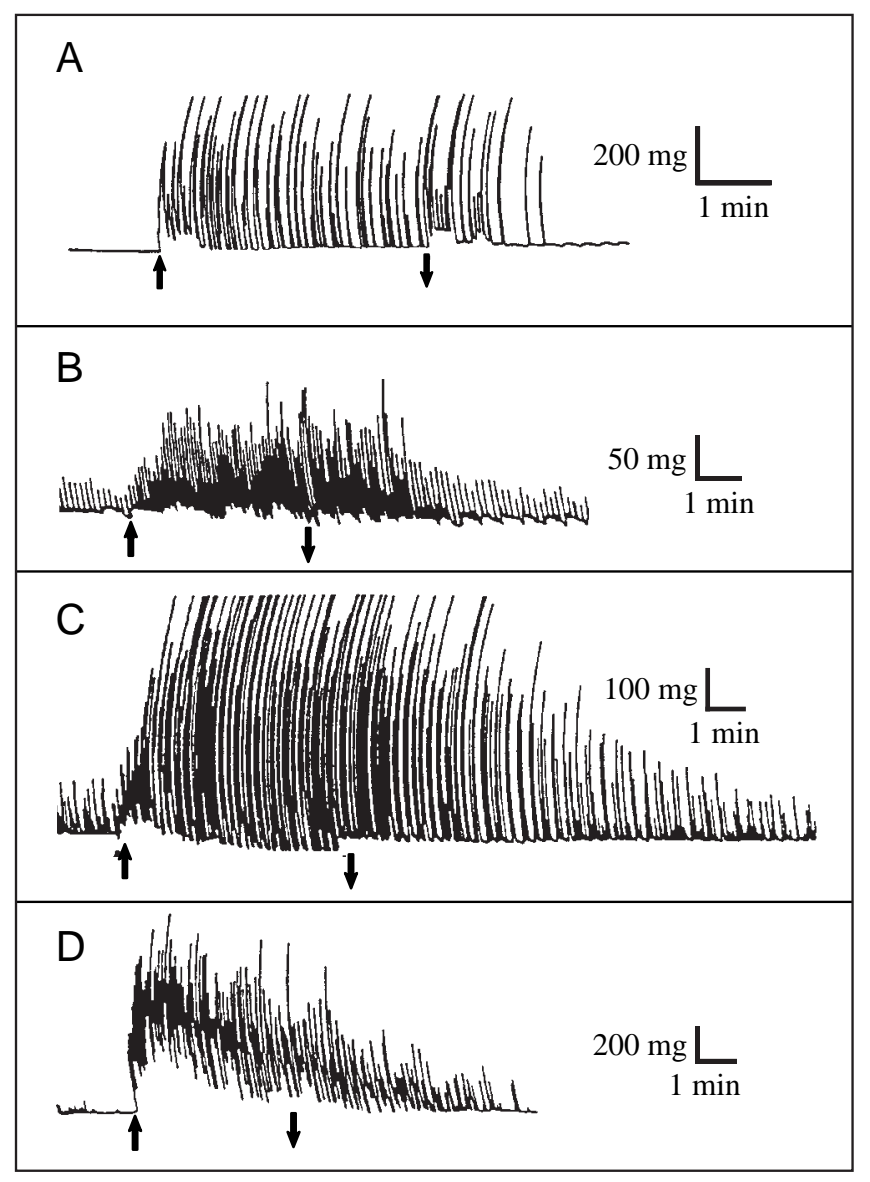

Fig. 5. Representative mechanograms showing the strong stimulatory actions of orcomyotropin (OMT) on contractions of inactive and spontaneously active hindguts of Orconectes limosus. (A) Induction of hindgut muscle contractions at $10^{-8} \mathrm{moll}^{-1}$ OMT. (B) Strong chronotropic effect at $10^{-10} \mathrm{moll}^{-1}$ OMT. (C) Strong inotropic effect at $10^{-8} \mathrm{moll}^{-1}$ OMT. (D) Distinct tonic effect at $10^{-7} \mathrm{moll} \mathrm{l}^{-1}$ OMT. The arrows indicate the start and end of exposure to OMT.

in three molluscan, two annelid and three insect peptides (Table 2). The DA sequence in OMT, MATP 1 and MATP $_{2}$ may also be of some significance. The myoactive tetradecapeptides (MATPs) display excitatory or inhibitory actions on various molluscan muscles (Ohta et al., 1990;

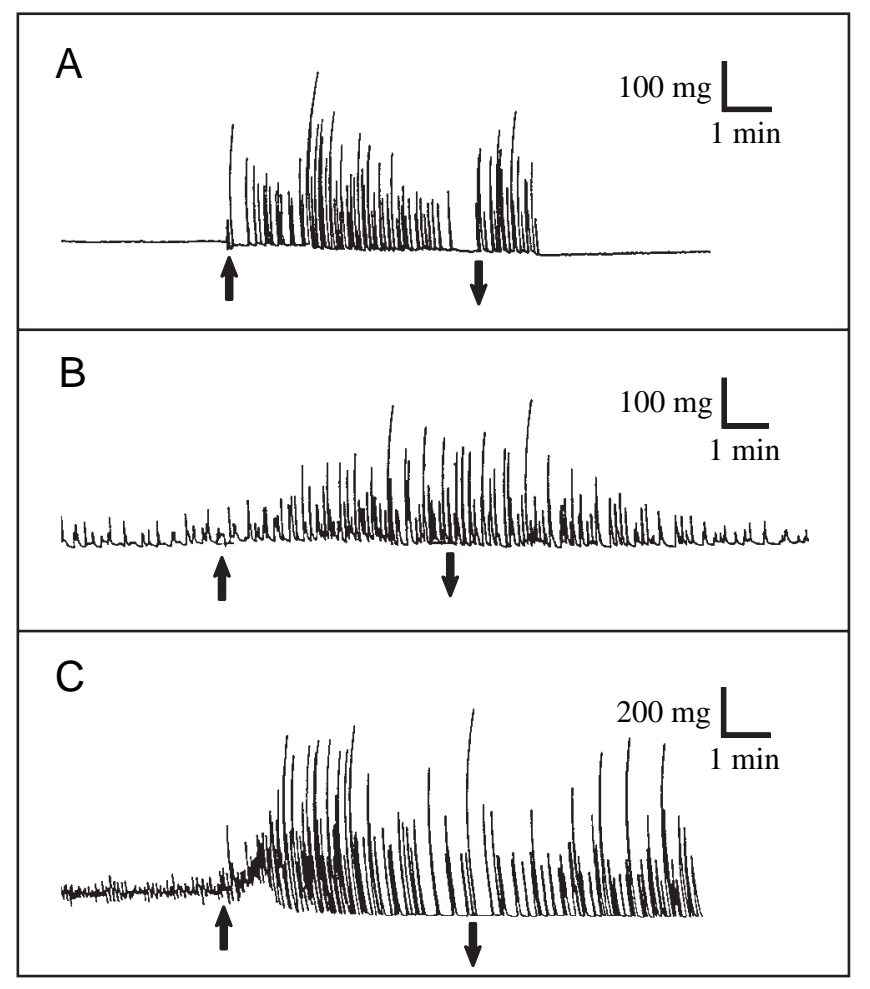

Fig. 6. Representative mechanograms showing the myotropic actions of synthetic $\mathrm{Val}^{13}$-orcokinin $\left(\mathrm{Val}^{13}-\mathrm{OK}\right)$ on hindguts of Orconectes limosus. (A) Induction of contractions at $10^{-9} \mathrm{moll}^{-1} \mathrm{Val}^{13}-\mathrm{OK}$ in an inactive hindgut. (B) Inotropic actions of $10^{-8} \mathrm{moll}^{-1} \mathrm{Val}^{13}$-OK on a spontaneously active hindgut. (C) Strong inotropic actions with an initial tonic component and slight chronotropic action of $10^{-6} \mathrm{moll}^{-1}$ $\mathrm{Val}^{13}$-OK on a spontaneously active hindgut. The arrows indicate the start and end of exposure to $\mathrm{Val}^{13}-\mathrm{OK}$.

Harada et al., 1993). Similar earthworm myoactive tetradecapeptides ETP and PTP show potent excitatory activity on spontaneous contractions of the anterior gut (Ukena et al., 1995). Allatotropin stimulates juvenile hormone synthesis in the corpora allata of Manduca sexta (Kataoka et al., 1989) and has been shown to have myotropic activity on the moth heart (Veenstra et al., 1994). These bioactivities have not yet been demonstrated for a recently identified allatotropin-related peptide in Aedes aegyptii (Veenstra and

Table 2. GF-amide peptides

\begin{tabular}{|c|c|c|c|}
\hline Name & Source & Primary structure & Reference \\
\hline OMT & Orconectes limosus & FDAFTTGF- $\mathrm{NH}_{2}$ & This study \\
\hline $\mathrm{FEP}_{4}$ & Fusinus ferrugineus & GFRMNSSNRVAHGF- $-\mathrm{NH}_{2}$ & Ohta et al. (1990) \\
\hline $\operatorname{MATP}_{1}\left(=\mathrm{AEP}_{3}\right)$ & Achatina fulica & GFRGDAASRVAHGF- $-\mathrm{NH}_{2}$ & Ohta et al. (1990) \\
\hline ETP & Eisenia foetida & GFKDGAADRISHGF- $\mathrm{NH}_{2}$ & Ukena et al. (1995) \\
\hline PTP & Pheretima vittata & GFRDGSADRISHGF-- $\mathrm{NH}_{2}$ & Ukena et al. (1995) \\
\hline Lom-AG-MT1 & $\begin{array}{l}\text { Locusta migratoria, } \\
\text { Leptinotarsa decemlineata }\end{array}$ & GFK*NVALSTARGF-NH 2 & $\begin{array}{l}\text { Paemen et al. (1990), } \\
\text { Spittaels et al. (1991) }\end{array}$ \\
\hline
\end{tabular}



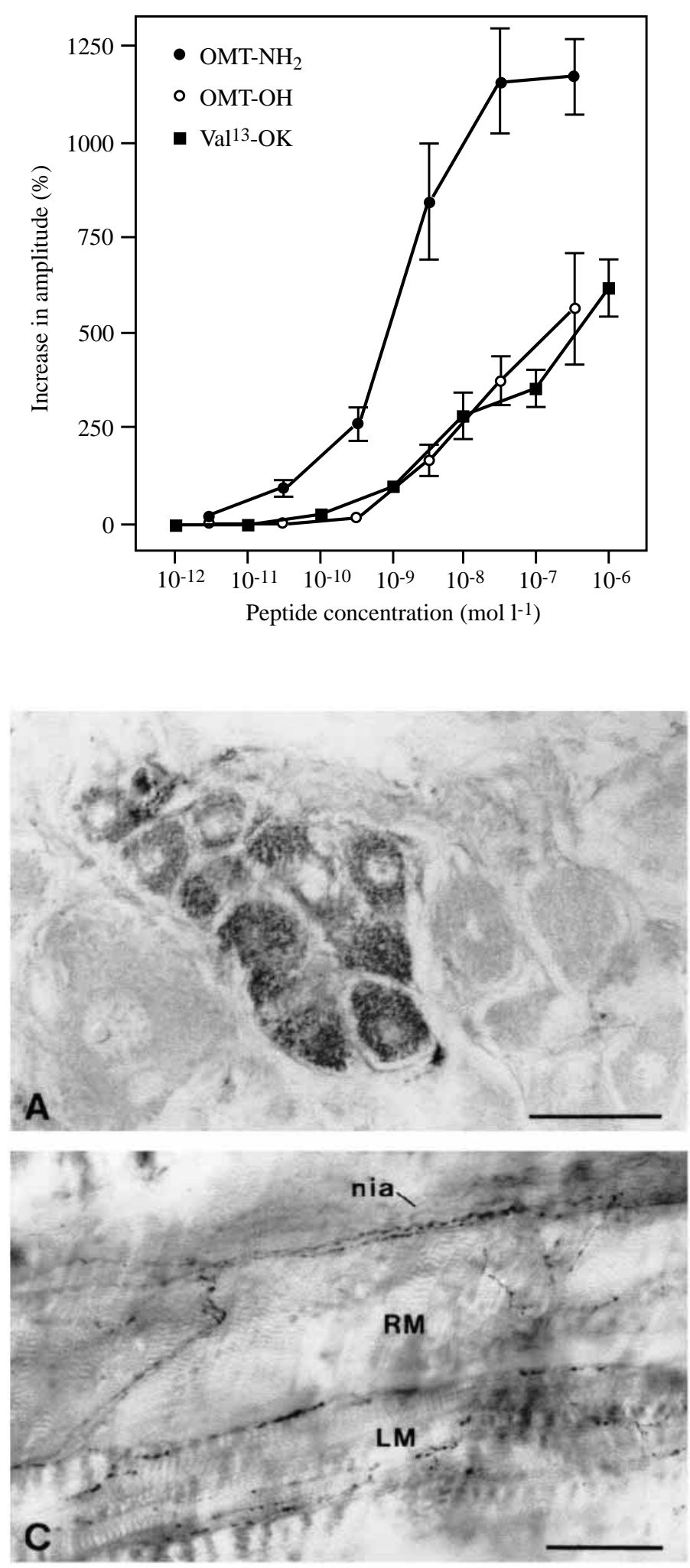

Fig. 7. Dose-response curves showing the effect of orcomyotropin (OMT-NH $\mathrm{N}_{2}$; filled circles), of its non-amidated analogue OMT-OH (open circles) and of $\mathrm{Val}^{13}$-orcokinin ( $\mathrm{Val}^{13}$-OK; filled squares) on the contraction amplitude of hindguts of Orconectes limosus. Values are means \pm S.E.M. $(N \geqslant 10)$.

Costes, 1999). Lom-AG-MT1, which was isolated first from the male accessory glands of Locusta migratoria and later from the Colorado potato beetle Leptinotarsa decemlineata, has potent oviduct-contracting activity (Paemen et al., 1991; Spittaels et al., 1996). In this context, it is interesting to note that OMT proved ineffective on the locust oviduct in the present study.

OMT is a very potent stimulator of crayfish hindgut contraction frequency and amplitude, the lowest effective concentration being approximately $5 \times 10^{-12} \mathrm{moll}^{-1}$. As shown in Fig. 7, the C-terminal amide group is essential for full biological activity. The non-amidated analogue is approximately 100 times less active. In the same assay, the activity of $\mathrm{Val}^{13}$-OK was also approximately 100 times lower

Fig. 8. Immunocytochemical demonstration of orcomyotropin (OMT)- and orkokinin (OK)-immunoreactive neurones in the terminal abdominal ganglion (A,B) and the hindgut (C,D) of Orconectes limosus. Adjacent serial sections treated on different slides showing OMT- (A) and OK- (B) immunoreactive cells in the posterior median cell (PMC) cluster of the sixth abdominal ganglion, whose neurones project into the nervus intestinalis. Note the somata showing co-localisation of the two peptides in the same neurones and unstained giant and other somata next to this group. (C,D) OMT- (C) and OK- (D) immunoreactive longitudinal and perpendicular fibres and terminals on the hindgut muscularis originating from PMC neurones. Note the fibres branching off from longitudinal nervi intestinales anteriores (nia) and terminals localised preferentially on longitudinal muscle fibre bundles (LM), but also on ring muscles (RM). Scale bars: $50 \mu \mathrm{m}(\mathrm{A}, \mathrm{B}), 100 \mu \mathrm{m}(\mathrm{C}, \mathrm{D})$. 


\section{H. DIRCKSEN AND OTHERS}

than that of OMT, with a threshold concentration of approximately $10^{-10} \mathrm{moll}^{-1}$. OK and $\mathrm{Val}^{13}-\mathrm{OK}$ have comparable potency (data not shown); thus, the influence of the C-terminal residue on the biological activity appears to be minor.

OMT and $\mathrm{Val}^{13}$-OK had virtually no effects on the hearts of $O$. limosus or $C$. maenas in assays on isolated or semiisolated in situ preparations, indicating that the heart is not the target organ of $\mathrm{Val}^{13}-\mathrm{OK}$ and OMT. The high level of OK-immunoreactivity, as quantified by ELISA (Bungart et al., 1994), and the immunocytochemical results on the distribution of OK- and OMT-immunoreactive material in the hindgut wall and in neurones of the terminal abdominal ganglion that project into the intestinal nerve clearly characterize the hindgut as a target organ in vivo. This innervation covers the entire hindgut, especially the prominent longitudinal muscles, which seem to be in direct contact, as judged at the light microscope level. These neurones have been described previously using neuroanatomical backfilling techniques as the efferent neurones innervating the hindgut muscles, and consist mainly of the posterior median cell cluster (PMC) and a few medial and lateral neurones (Elekes et al., 1988; Audehm et al., 1993). The PMC neurones, however, are different from the segmentally homologous CCAP-immunoreactive neurones that occur in each ganglion of the entire ventral nerve cord (Audehm et al., 1993; Trube et al., 1994). The CCAP neurones in the three neuromers of the terminal ganglion adjacent to the PMC cluster densely innervate certain telson muscles, but also contribute axons within and close to the surface of the intestinal nerve. A subset of these CCAP neurones from the posterior medial lateral cell cluster (PMLC cluster; Audehm et al., 1993) terminates in the so-called periintestinal ring (Baumann, 1918) where it forms a neurohaemal area in a posterior hindgut haemolymph space instead of innervating hindgut muscles. Innervation of the hindgut is probably almost exclusively by the OK/OMTimmunoreactive neurones of the PMC cluster. Some of these neurones may also contain catecholamines (Elofsson et al., 1968; Mercier et al., 1991) or may even be associated or colocalised with the proctolin- or FMRFamide-containing neurones that also innervate hindgut muscles (Mercier et al., 1997). Further experimentation is needed to resolve these issues.

OMT and $\mathrm{Val}^{13}$-OK proved ineffective on the locust hindgut and oviduct. For control purposes, proctolin and CCAP were applied to the same preparations and were found to be strongly effective at equimolar or lower concentrations. Other crustacean myotropins, the recently identified tachykinin- and two kinin-like (Pev-tachykinin and Pev-kinins I and II) peptides were found to be effective on insect hindguts (Christie et al., 1997; Nieto et al., 1998). In view of the fact that the locust hindgut responds to a huge variety of myotropic peptides (Schoofs et al., 1997), it is interesting to note that OMT, a peptide with a C-terminal GFamide motif, corresponding, for example, to the $\mathrm{C}$ terminus of Lom-AG MT I, a potent hindgut and oviduct contracting substance, is inactive. The presence of $\mathrm{Val}^{13}$-OK or other analogs of the OK family in insects has yet to be tested.

This work was supported by a grant from the Deutsche Forschungsgemeinschaft to R.K. (Ke 206/7-9). We wish to thank Dr Caroline Hilbich (Center for Molecular Biology, Heidelberg, Germany) for carrying out the automated gasphase sequencing, the late Dr Günter Kegel (Institut für Zoophysiology, Bonn) for the amino acid analyses and Dr Dieter Bungart (Institut für Zoophysiology, Bonn) for carrying out the peptide syntheses.

\section{Note added in proof}

In a recent paper (Yasuda-Kamatani, Y. and Yasuda, A., 2000. Gen. Comp. Endocrinol. 118, 161-172) two slightly different orcokinin (OK)-precursor cDNAs from the crayfish Procambarus clarkii have been described. Both precursors contain several copies of $\mathrm{Asn}^{13}-\mathrm{OK}$, one copy of $\mathrm{Val}^{13}-\mathrm{OK}$ and two other novel OK-analogues. In addition, one peptide of the sequence FDATTGFGHS, which is similar to orcomyotropin (OMT) of crayfish $O$. limosus except for three additional Cterminal residues, can be deduced from both precursors, but has not been identified as a mature peptide. The occurrence of an OMT-like peptide together with OKs in one precursor of a closely related species might explain the immunocytochemical colocalisation described in $O$. limosus in the present paper.

\section{References}

Atherton, E. and Sheppard, R. C. (1989). Solid Phase Peptide Synthesis: A Practical Approach. Oxford: IRL Press.

Audehm, U., Trube, A. and Dircksen, H. (1993). Patterns and projections of crustacean-cardioactive-peptide-immunoreactive neurones of the terminal ganglion of crayfish. Cell Tissue Res. 272, 473-485.

Averof, M. and Akam, M. (1995). Insect-crustacean relationship: insights from comparative developmental and molecular studies. Phil. Trans. R. Soc. Lond. B 347, 293-303.

Baumann, H. (1918). Das Gefäßsystem von Astacus fluviatilis (Potamobius astacus L.). Z. Wiss. Zool. 118, 246-312.

Bennett, H. P. J., Browne, C. A., Goltzman, D. and Solomon, S. (1974). Isolation of peptide hormones by reversed-phase high pressure liquid chromatography. In Peptides: Structure and Biological Function, vol. 6 (ed. E. Gross and J. Meienhofer), pp. 121-124. Rockford, IL: Pierce Chemical Co.

Biemann, K. (1992). Mass spectrometry of peptides and proteins. Annu. Rev. Biochem. 61, 977-1010.

Bungart, D., Dircksen, H. and Keller, R. (1994). Quantitative determination and distribution of the myotropic neuropeptide orcokinin in the nervous system of astacidean crustaceans. Peptides 15, 393-400.

Bungart, D., Hilbich, C., Dircksen, H. and Keller, R. (1995a). Occurrence of analogs of the myotropic neuropeptide orcokinin in the shore crab Carcinus maenas: evidence for a novel neuropeptide family. Peptides 16, 67-72.

Bungart, D., Kegel, G., Burdzik, S. and Keller, R. (1995b). 
Structure-activity relationships of the crustacean myotropic neuropeptide orcokinin. Peptides 16, 199-204.

Christie, A. E., Lundquist, C. T., Nässel, D. R. and Nusbaum, M. P. (1997). Two novel tachykinin-related peptides from the nervous system of the crab Cancer borealis. J. Exp. Biol. 200, 2279-2294.

Dircksen, H. (1994). Distribution and physiology of crustacean cardioactive peptide in arthropods. In Perspectives in Comparative Endocrinology (ed. K. G. Davey, R. E. Peter and S. S. Tobe), pp. 139-147. Ottawa: National Research Council of Canada.

Dircksen, H. and Keller, R. (1988). Immunocytochemical localization of CCAP, a novel crustacean cardioactive peptide, in the nervous system of the shore crab, Carcinus maenas L. Cell Tissue Res. 254, 347-360.

Dircksen, H., Müller, A. and Keller, R. (1991). Crustacean cardioactive peptide in the nervous system of the locust, Locusta migratoria: an immunocytochemical study on the ventral nerve cord and peripheral innervation. Cell Tissue Res. 263, 439-457.

Dircksen, H., Skiebe, P., Abel, B., Agricola, H., Buchner, K., Muren, J. E. and Nässel, D. R. (1999). Structure, distribution and biological activity of novel members of the allatostatin family in the crayfish Orconectes limosus. Peptides 20, 695-712.

Duve, H., Johnsen, A. H., Maestro, J. L., Scott, A. G., Jaros, P. P. and Thorpe, A. (1997). Isolation and identification of multiple neuropeptides of the allatostatin superfamily in the shore crab Carcinus maenas. Eur. J. Biochem. 250, 727-734.

Duve, H., Thorpe, A., Johnsen, A. H., Maestro, J. L., Scott, A. G. and East, P. D. (1998). The dipteran Leu-callatostatins: structural and functional diversity in an insect neuroendocrine peptide family. In Recent Advances in Arthropod Endocrinology, vol. 65 (ed. G. M. Coast and S. G. Webster), pp. 229-247. Cambridge: Cambridge University Press.

Elekes, K., Florey, E. and Cahill, M. A. (1988). Morphology and central synaptic connections of the efferent neurons innervating the crayfish hindgut. Cell Tissue Res. 254, 369-379.

Elofsson, R., Kauri, T., Nielsen, S. O. and Stroemberg, J. O. (1968). Catecholamine-containing nerve fibres in the hindgut of the crayfish Astacus astacus L. Experientia 24, 1159-1160.

Friedrich, M. and Tautz, D. (1995). Ribosomal DNA phylogeny of the major extant arthropod classes and the evolution of myriapods. Nature 376, 165-167.

Gäde, G. (1997). The explosion of structural information on insect neuropeptides. In Progress in the Chemistry of Organic Natural Products, vol. 71 (ed. W. Herz, G. W. Kirby, R. E. Moore, W. Steglich and C. Tamm), pp. 1-97. Vienna, New York: Springer.

Gäde, G., Hoffmann, K. H. and Spring, J. H. (1997). Hormonal regulation in insects: facts, gaps and future directions. Physiol. Rev. 77, 963-1032.

Harada, A., Yoshida, M., Minakata, H., Nomoto, K., Muneoka, Y. and Kobayashi, M. (1993). Structure and function of the molluscan myoactive tetradecapeptides. Zool. Sci. 10, 257-265.

Hunt, D. F., Yates, J. R. I., Shabanovitz, J., Bruns, M. E. and Bruns, D. E. (1989). Amino acid sequence analysis of two mouse calbindin-D9K isoforms by tandem mass spectrometry. J. Biol. Chem. 264, 6580-6486.

Hunt, D. F., Yates, J. R. I., Shabanovitz, J., Winston, S. and Hauer, C. R. (1986). Protein sequencing by tandem mass spectrometry. Proc. Natl. Acad. Sci. USA 83, 6233-6237.

Kataoka, H., Toshi, A., Li, J. P., Carney, R. L., Schooley, D. A. and Kramer, S. J. (1989). Identification of an allatotropin from adult Manduca sexta. Science 243, 1481-1483.
Keim, W. (1915). Das Nervensystem von Astacus fluviatilis (Potamobius astacus) L. Z. Wiss. Zool. 113, 485-545.

Keller, R. (1992). Crustacean neuropeptides: structures, functions and comparative aspects. Experientia 48, 439-448.

Krajniak, K. G. (1991). The identification and structure-activity relations of a cardioactive FMRFamide-related peptide from the blue crab Callinectes sapidus. Peptides 12, 1295-1302.

Kuster, T., Staudenmann, W., Hughes, G. J. and Heizmann, C. W. (1991). Parvalbumin isoforms in chicken muscle and thymus. Amino acid sequence analysis of muscle parvalbumin by tandem mass spectrometry. Biochemistry 30, 8812-8816.

Lange, A. B. (1987). Mode of action of proctolin on locust visceral muscle. Arch. Insect Biochem. Physiol. 24, 79-92.

Mercier, A. J., Lange, A. B., TeBrugge, V. and Orchard, I. (1997). Evidence for proctolin-like and RFamide-like neuropeptides associated with the hindgut of the crayfish Procambarus clarkii. Can. J. Zool. 75, 1208-1225.

Mercier, A. J., Orchard, I. and Schmoeckel, A. (1991). Catecholaminergic neurons supplying the hindgut of the crayfish Procambarus clarkii. Can. J. Zool. 69, 2778-2785.

Mercier, A. J., Orchard, I., TeBrugge, V. and Skerrett, M. (1993). Isolation of two FMRFamide-related peptides from crayfish pericardial organs. Peptides 14, 137-143.

Nieto, J., Veelaert, D., Derua, R., Waelkens, E., Cerstiaens, A., Coast, G., Devreese, B., Van Beeumen, J., Calderon, J., De Loof, A. and Schoofs, L. (1998). Identification of one tachykinin- and two kinin-related peptides in the brain of the white shrimp, Penaeus vannamei. Biochem. Biophys. Res. Commun. 248, 406-411.

Ohta, N., Kanda, T., Kuroki, Y., Kubota, I., Muneoka, Y. and Kobayashi, M. (1990). Three novel tetradecapeptides isolated from the ganglia of the molluscs Achatina fulica and Fusinus ferrugineus. In Peptide Chemistry 1989 (ed. N. Yanaihara), pp. 57-62. Osaka, Japan: Protein Research Foundation.

Orlov, J. (1926). Die Innervation des Darmes des Flußkrebses. Z. Mikr. Anat. Forsch. 4, 101-148.

Paemen, L., Tips, A., Schoofs, L., Proost, P., Van Damme, J. and De Loof, A. (1991). Lom-AG-myotropin: a novel myotropic peptide from the male accessory glands of Locusta migratoria. Peptides 12, 7-10.

Pantin, C. F. A. (1934). A saline for Carcinus maenas. J. Exp. Biol. 11, 11-27.

Price, D. A. and Greenberg, M. J. (1989). The hunting of the FaRPs: the distribution of FMRFamide-related peptides. Biol. Bull. 177, 198-205.

Schoofs, L., Veelaert, D., Vanden Broeck, J. and De Loof, A. (1997). Peptides in the locusts, Locusta migratoria and Schistocerca gregaria. Peptides 18, 145-156.

Sithigorngul, P., Saraithongkum, W., Jaideechoey, S., Longyant, S. and Sithigorngul, W. (1998). Novel FMRFamide-like neuropeptides from the eyestalk of the giant freshwater prawn Macrobrachium rosenbergii. Comp. Biochem. Physiol. 120B, 587-595.

Skiebe, P. and Schneider, H. (1994). Allatostatin peptides in the crab stomatogastric nervous system: inhibition of the pyloric motor pattern and distribution of allatostatin-like immunoreactivity. $J$. Exp. Biol. 194, 195-208.

Spittaels, K., Vankeerberghen, A., Schoofs, L., Proost, P., Van Damme, J. and De Loof, A. (1996). Isolation and characterization of Locusta migratoria accessory gland myotropin I (Lom-Ag-MT-I) from the brain of the Colorado potato beetle, Leptinotarsa decemlineata. Arch. Insect Biochem. Physiol. 31, 149-155. 


\section{H. DIRCKSEN AND OTHERS}

Stangier, J. (1992). Biological effects of crustacean cardioactive peptide (CCAP), a putative neurohormone/neurotransmitter from crustacean pericardial organs. In Comparative Aspects of Neuropeptide Function, vol. 2 (ed. E. Florey and G. B. Stefano), pp. 201-210. Oxford: Pergamon Press.

Stangier, J., Hilbich, C., Burdzik, S. and Keller, R. (1992). Orcokinin: a novel myotropic peptide from the nervous system of the crayfish, Orconectes limosus. Peptides 13, 859-864.

Stefanini, M., De Martino, C. and Zamboni, L. (1967). Fixation of ejaculated spermatozoa for electron microscopy. Nature 216, 173-174.

Trimmer, B. A., Kobierski, L. A. and Kravitz, E. A. (1987). Purification and characterization of FMRFamide-like immunoreactive substances from the lobster nervous system: isolation and sequence analysis of two closely related peptides. $J$. Comp. Neurol. 266, 16-26.

Trube, A., Audehm, U. and Dircksen, H. (1994). Crustacean cardioactive peptide-immunoreactive neurons in the ventral nervous system of crayfish. J. Comp. Neurol. 348, 80-93.

Ukena, K., Oumi, T., Matsushima, O., Ikeda, T., Fujita, T.,
Minakata, H. and Nomoto, K. (1995). A novel gut tetradecapeptide isolated from the earthworm, Eisenia foetida. Peptides 16, 995-999.

Van Harreveld, A. (1936). A physiological solution for freshwater crustaceans. Proc. Soc. Exp. Biol. Med. 34, 428-432.

Veelaert, D., Schoofs, L. and De Loof, A. (1998). Peptidergic control of the corpus cardiacum-corpora allata complex of locusts. Int. Rev. Cytol. 182, 249-302.

Veenstra, J. A. and Costes, L. (1999). Isolation and identification of a peptide and its cDNA from the mosquito Aedes aegypti related to Manduca sexta allatotropin. Peptides 20, 1145-1151.

Veenstra, J. A., Lehman, H. K. and Davis, N. T. (1994). Allatotropin is a cardioacceleratory peptide in Manduca sexta. $J$. Exp. Biol. 188, 347-354.

Weaver, R. J., Edwards, J. P., Bendena, W. G. and Tobe, S. S. (1998). Structures, functions and occurrences of insect allatostatic peptides. In Recent Advances in Arthropod Endocrinology, vol. 65 (ed. G. M. Coast and S. G. Webster), pp. 3-32. Cambridge: Cambridge University Press. 